$\begin{array}{ll} & \text { Etnográfica } \\ \text { etnográfica } & \text { Revista do Centro em Rede de Investigação em }\end{array}$

Antropologia

vol. 18 (1) | 2014

Vol. $18(1)$

\title{
The many faces of Baltasar da Costa: imitatio and accommodatio in the seventeenth century Madurai mission
}

As máscaras de Baltasar da Costa: imitatio e accommodatio na missão de Madurai (século XVII)

\section{Ananya Chakravarti}

\section{(2) OpenEdition}

\section{Journals}

Electronic version

URL: https://journals.openedition.org/etnografica/3376

DOI: 10.4000/etnografica.3376

ISSN: 2182-2891

\section{Publisher}

Centro em Rede de Investigação em Antropologia

Printed version

Date of publication: 1 February 2014

Number of pages: 135-158

ISSN: 0873-6561

\section{Electronic reference}

Ananya Chakravarti, "The many faces of Baltasar da Costa: imitatio and accommodatio in the seventeenth century Madurai mission", Etnográfica [Online], vol. 18 (1) | 2014, Online since 14 March 2014, connection on 10 February 2022. URL: http://journals.openedition.org/etnografica/3376 ; DOI: https://doi.org/10.4000/etnografica.3376

\section{(c) (7) \&}

Etnográfica is licensed under a Creative Commons Attribution-NonCommercial 4.0 International License. 


\section{The many faces of Baltasar da Costa: imitatio and accommodatio in the seventeenth century Madurai mission}

\section{Ananya Chakravarti}

The Jesuit Baltasar da Costa devoted his life to the Madurai mission in seventeenth century Tamil Nadu during the rule of the Nāyaka kings. He was the first Christian missionary to style himself as a panțāram, a Śaiva priest to the lower castes. This paper will argue that his mimetic practice can best be appreciated if read bi-directionally, through the language of European humanism and religious thought, as well as through the new symbolic codes of Nãyaka political order. The article also considers the limits of Costa's mimetic practice in terms of its success as an evangelical strategy and in the extent to which it was ultimately predicated upon the maintenance of alterity and not the dissolution of difference.

KEYWORDS: mimesis, Jesuit missionaries, Madurai, Portuguese imperialism.

As máscaras de Baltasar da Costa: imitatio e accommodatio na missão de Madurai (século XVII) - O jesuíta Baltasar da Costa dedicou a sua vida à missão de Madurai em Tamil Nadu, durante o governo dos reis Nãyaka, no século XVII. Este artigo argumenta que a sua prática mimética pode ser apreciada quando entendida de forma bidirecional, através da linguagem do humanismo e do pensamento religioso europeus, bem como através dos novos códigos simbólicos da ordem política Nāyaka. Consideram-se também os limites da prática mimética de Costa, em termos do seu sucesso como prática evangélica e, ainda, atendendo ao facto de pressupor, em última instância, a manutenção da alteridade em vez da dissolução da diferença.

PALAVRAS-CHAVE: mimese, missionários jesuítas, Madurai, imperialismo português.

CHAKRAVARTI, Ananya (ananya.chakravarti@aucegypt.edu) - Department of History, The American University in Cairo, Egypt. 


\title{
WHITE-FACES IN THE TAMIL COUNTRY
}

\begin{abstract}
"Krisānu: There is nothing meaner than the Hūnas in this world, who disregard the Brahmins and count them as bits of grass. Their villainy is inexpressible... Riches are bestowed on the impure Hūnas and adversity on the good... Ah! Creator thou hast made such difficulty...

Viśvāsu: [The Hūnas] would not unjustly extort the property of others and [they] never speak false; they invent wondrous articles and inflict punishment on convicts by the law: observe this virtue of the mischievous Hūnas" (Venkațādhvarin 1825 78).
\end{abstract}

The above words, penned by the poet Ven kațādhvarin, described the whitefaces (śvetavadanāh) of the seventeenth-century Tamil country. ${ }^{1}$ Here, after the dissolution of the Vijayanagara empire, Telegu warriors had transformed themselves into śudra kings, turning traditional caste discourse on its head. Under these Nāyaka kings, lower-caste magnates grew powerful through the accumulation of wealth, while customary land donations to Brahmins decreased. In this brazenly new order, European interlopers of all stripes sought to make their place and it was of these foreigners that the poet spoke, using two mythological beings, the gandharvas, as his mouthpieces. Krisānu, "a reviler perpetually seeking the path of evil" (Veñkațādhvarin 1825: 2) expressed Brahminical contempt for these mlecchas (foreigners beyond the pale of caste society) who cared nothing for norms of purity or hygiene, and whose missionaries were actively engaged in undermining Brahminical authority. Moreover, these "Huns" (Hünas) were enriching themselves in the highly commercialized Nāyaka states, even as the Brahmins suffered financially. Viśvāsu, "who only searched for the virtues in the universe" (Venkațādhvarin 1825: 2 ), cheerfully celebrated the commercial abilities and ethics of the Europeans, undoubtedly valued at the mercantile Nāyaka courts, where the "wondrous things" of the Europeans were coveted as curiosities.

This two-faced discourse expressed the almost contradictory views of Europeans current in seventeenth-century Tamil Nadu but more generally, it was typical both of the time and of this particular poet: Venkațādhvarin was also the author of Yãdavaräghavizya, an example of a rare and recently invented genre of bi-directional Sanskrit poetry (vilomakävya). ${ }^{2}$ This text read in one

I This paper is an output of the research project "Colonial Mimesis in Lusophone Asia and Africa", funded by Fundação para a Ciência e a Tecnologia (PTDC/CS-ANT/101064/2008). The author thanks the project team members, Cristiana Bastos, Ricardo Roque, Tiago Saraiva and Ângela Barreto Xavier, for their valuable comments and critiques on an earlier version of this paper. Thanks are also due to the anonymous reviewer for their constructive comments, which helped me to improve the manuscript.

2 This genre, invented in 1580 by Suryadasa, who had learnt Perso-Arabic script, was a response to a new knowledge system (Minkowski 2004). On the surge in popularity in this period of śleșa or simultaneous narration in Sanskrit, Tamil and Telegu poetry, see Bronner (2010). 


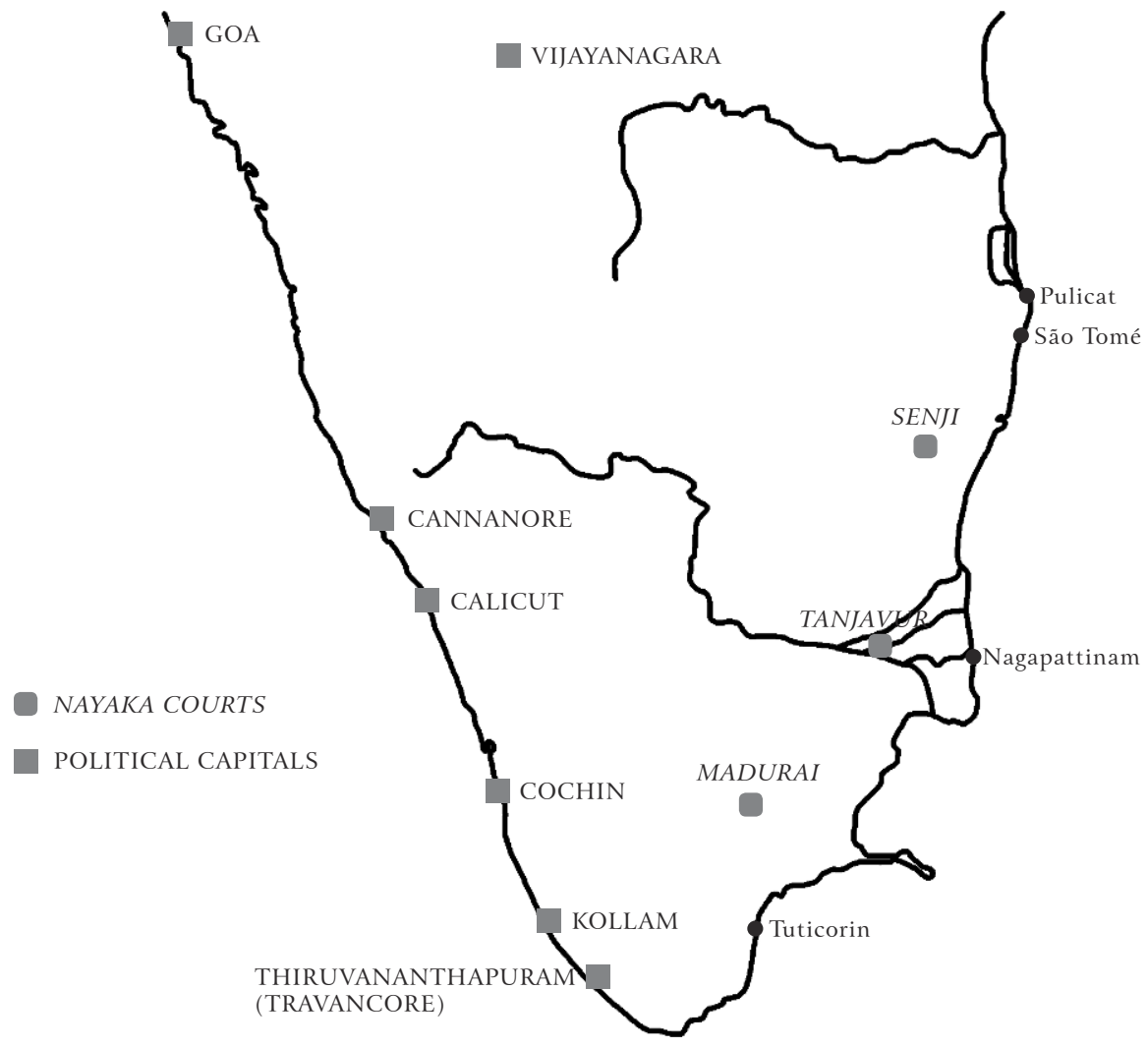

Figure 1 - Southern India, $16^{\text {th }}$-mid $17^{\text {th }}$ centuries. Based on Subrahmanyam (2002: 34).

direction told the story of the exemplary dharmic king Rāma, and in the other recounted the exploits of the divine lover, Kṛṣa, two opposed qualities which Nāyaka kingship innovatively sought to subsume within itself (Rao, Shulman and Subrahmanyam 1993). The text thus brilliantly expressed the new symbolic structure of power in the Nāyaka states through this generic innovation and was thus a prime exponent of a new cultural order in which multivalent and multi-faceted forms of identity-making were rife.

In this sense, Veñ kațādhvarin's contemporary, the Portuguese Jesuit Baltasar da Costa, was a typically Nāyaka figure, displaying not only a deep understanding of these new symbolic expressions of power but remarkable creativity in re-making his own identity in this context. Still, as a Jesuit missionary who came to the Tamil country with the bored ears and garb of a panțāram (a Śaiva priest to the lower castes) to teach the word of Christ, how did Costa fit into the schema of Europeans so skillfully sketched by Venkațādhvarin? How did he fit into the broader cultural order of the Nāyaka realm? Moreover, how did Costa himself understand his life and career as a panțāram Jesuit? 
What follows is a historical analysis of the career of Baltasar da Costa in the spirit of vilomakāvya. Costa's mimetic practice can best be appreciated if read bi-directionally, through the language of European humanism and religious thought, as well as through the new symbolic codes of Nāyaka political order. By virtue of his faith and vocation, Costa's mimesis of pagan priests could not risk radical personal transformation of the sort which he wished to effect in his subjects through conversion. Thus, the goal of Costa's mimetic practice, turning on the interplay of imitatio and accommodatio, was to render himself legible both to his European audience as a Jesuit missionary and to Nāyaka society as a recognizable source of religious authority. By remaining insistently simultaneous, the process of mimesis was always open to rupture and refused the teleology implied by the existence of an original. It is this attempt to render himself simultaneously legible to European and Nāyaka society that requires a bi-directional reading of his mimetic practice.

It is important to note in this light that Costa's mimetic practice was both derivative and pioneering. In molding himself in the fashion of a pagan priest, he was following the method outlined by the founder of the accommodationist mission at Madurai, Roberto Nobili. By drawing a crucial ontological distinction between religious and civil aspects of Tamil society, Nobili had paved the way for a missionary practice which depended on the exorcism of idolatrous elements that left Tamil culture "a tree of signs primarily in need of correct interpretation" (Županov 1999: 104). In Nobili's case, his interpretation had been shaped by his Brahminical interlocutors, such that he predicated his own mimetic practice on the model of the Brahmin ascetic. As one anthropologist of Tamil Christianity has put it:

"Nobili's ontological separation of 'the religious' and 'the civil' (or political), the transcendent sacred and the relegated profane, would reappear in different guise in the highly Brahmanical twentieth-century anthropology of Louis Dumont [...] Jesuits did first what colonial officers and anthropologists would do later - that is, construct knowledge through an 'intercultural mimesis,' coming to knowledge about India through a relationship with Brahmans and their view of society - not a Brahman point of view per se, but an imitation of Brahman theorizing [...] " (Mosse 2012: 9).

Costa instead came to the Madurai mission in the ready-made guise of a panțāram, in conformity with the instructions he had received from his superiors. His reading of Nāyaka society flowed from the mimetic social position he had been assigned and which contrasted sharply with the Brahminical theorization of Nobili. Yet, Costa was always aware that his was a missionary practice based on a double-mimesis, whose objects were both the panțāram and his revered predecessor, Nobili, again necessitating the bi-directional reading essayed below. 
This article begins with a brief history of the Madurai mission, before turning to Costa's ethnography of Nāyaka society and his critique of Roberto Nobili, the Jesuit who had first elaborated a mimetic model of missionary work in Madurai. In light of his understanding of his missionary field, one can better read Costa's mimetic practice as a complex interplay of imitatio and accommodatio that rendered him legible to both Nāyaka and European society. Finally, the article considers the limits of Costa's mimetic practice in terms of its success as an evangelical strategy and in the extent to which it was ultimately predicated upon the maintenance of alterity and not the dissolution of difference.

\section{THE MADURAI MISSION, NĀYAKA POWER AND CASTE}

The Malabar province of the early seventeenth century was beset politically, economically and militarily by the Dutch, to whom the Portuguese temporal allies of the Jesuits were quickly losing ground, and riddled with controversy on the ecclesiastical front. On both coasts of southern India, the hegemony of the Jesuits was beginning to erode. ${ }^{3}$ In this landscape, the Madurai mission, in the shadow of burgeoning Nāyaka power, would prove an unlikely bright spot. It had begun inauspiciously - from 1595 to 1606, when Roberto Nobili arrived, Gonçalo Fernandes managed to effect not a single conversion, tending instead to Parava converts who emigrated from the Fishery Coast or visited Madurai for trade. Nobili realized that Fernandes and his converts lived outside recognized social hierarchy, as members of the unclean parangi kulam, the caste of foreigners. Recognizing this barrier to conversion, Nobili experimented with new modes of self-presentation based first upon his noble lineage and eventually on the model of a Brahmin ascetic. Nobili acquiesced to brahminical custom not only in his person, but also by making important concessions to his high-caste neophytes, allowing them to maintain separation from lower caste converts, retain the pünül (sacred thread), the kudumi (tuft of hair), and the practices of ablutions and wearing sandal paste. ${ }^{4}$ Nobili himself went to confess to Fernandes in secret at night, a practice which was later

3 The Jesuits were involved in bitter controversy with the St. Thomas Christians since Francisco Ros was appointed bishop of Ankamali. See, for example, Archivo Storico della Sacra Congregazione per l'Evangelizzazione dei Popoli de Propaganda Fide, Scritture Originali Riferite nelle Congregazioni Generali (SOCG), APF, SOCG, 98 (Lettere Spagna, Portogallo Indie Svizzera Colonia 1630), f. 81. The dual bishoprics in the region further complicated the mission field, as the jurisdictional dispute between the Jesuits with the Bishop of Cochin, the Franciscan André de Santa Maria, over control of the Paravas shows. For the Jesuit view, see Queyroz (1689: 60-120). For an anti-Jesuitical interpretation, see APF, SOCG, 40 (Orientali Relazioni), "Historia della costa de Pescaria, 1633", ff. 506-516.

4 Paolo Aranha (2008) has shown just how radical some of the accommodations effected by Nobili were, particularly in death rituals. 
extended by the missionaries to lower caste converts so as not to jeopardize their standing among the higher castes.

Nobili's innovations deeply offended Gonçalo Fernandes, who perceived them as not only a dangerous descent into paganism but also an affront to the Portuguese, who were closely identified with the parangi identity from which Nobili had worked so hard to distance himself. A theological and ethnographic debate ensued, before Nobili's erudite arguments and political sophistication prevailed in 1623.5 Still, though Nobili undoubtedly revived the moribund mission, even with all these concessions the Brahmin converts in 1622 only numbered twenty-nine.

The issue of caste, despite Nobili's innovations, had continued to blight the mission. In 1638, amidst a series of uplifting narratives of conversions, Manuel Martins included this case:

"A case I want to recount illumines the variety of modes that divine providence takes in gathering its chosen. A man of the merchant caste, honored among castes, joined with the Christian Paravas, by caste fishermen, one of the inferiors of this land that they cultivate on the Fishery Coast. As by taking this mission most converts in India lose their caste and are reputed for low caste with whom the honored gentiles do not deal in the political customs, because they cannot distinguish between political and religious customs, no sooner had this merchant received our law, which he did to marry a fisherwoman of whom he was enamored and who was Christian, than he was cast out of his caste, despised by relatives, among them an older sister who is now a widow. But since marriages of reckless affection often do not end well, this merchant

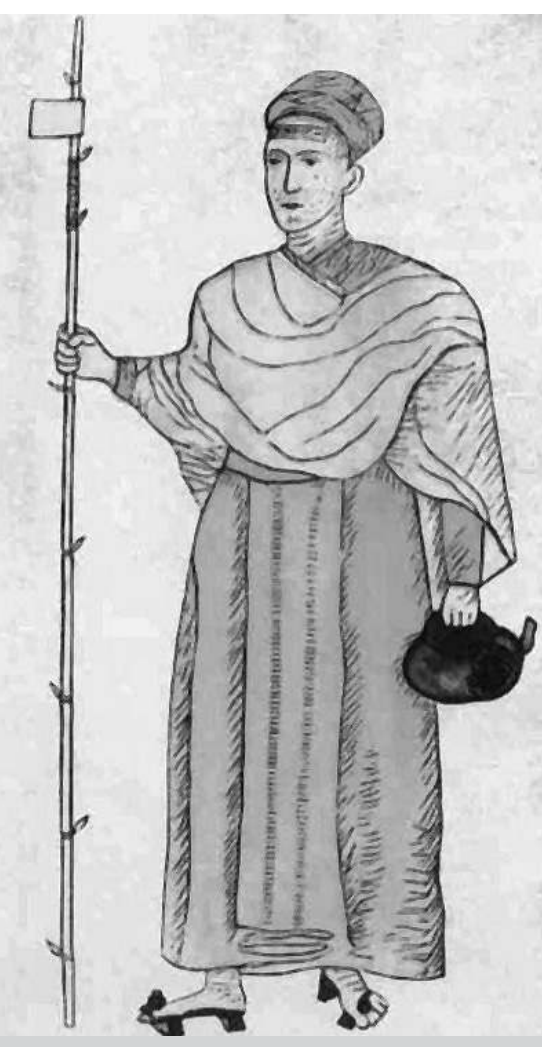

Figure 2 - Baltasar da Costa's sketch of Roberto Nobili as a Sannyāsi. Source: Baltasar da Costa, 1661, Catecismo em Que se Explicão Todas as Verdades Catholicas Necessárias pera a Salvação com Excellentissima Ordem, Lisbon, Academia das Ciências. 
after many years passed with many troubles with the woman, finally left not only her but went inland to the land of the gentiles in search of his sister whom he had left [...] What is certain is that he hid the insignia of the Christians so as not to displease, [and] lived thus for some months."

Given the genre of the text, it could not but fail to have a salutary ending - the merchant found that his sister in the meanwhile had heard the Christian law, as "distinct from caste" and from "political customs," and had been convinced of its truth. Upon being shown various sacred images and a crucifix, she had declared to the priest that she already recognized the cross, as it was frequently found outside the gates of churches and she had spent her childhood close to a Parava village. She revealed that she had not understood it as a sign of the sacred mysteries but merely as something that the lower castes adored. ${ }^{7}$ Nonetheless, even after she received baptism and Martins gave her crucifixes of wood, she balked, asking for one of glass. Martins explained that since the Paravas commonly wore crucifixes of wood on their chests, great "disgust" had affected her "imagination" of these "insignias of the low people," and that even though she revered the cross, she dared not accept one unless it were of a different material. Nonetheless, Martins claimed, both brother and sister lived, "with no fear of disgrace," as Christians in their "interior and exterior."

Martins' narrative bristled with tensions. With some reluctance he had been forced to admit that he original impetus of the merchant's conversion and willingness to join the low caste Parava was the desire to marry a Parava girl. In explaining the consequences of this conversion, even as he adhered to Nobili's definition of caste as a social or political custom independent of religion, Martins was forced to concede that the members of caste society themselves were unaware of this distinction. His description of the sister's conversion is even more revealing of the popular perception of the Christian faith and the powerful disgust at its association with the lower castes that could continue to pervade the imaginations of even converts. Yet, he insisted that they were Christians inside and out. The internal contradictions and limitations of Nobili's position on caste and its consequences for the mission were apparent. It would thus have come as little surprise when Martins concluded the report by noting that in that year fifty people of honored castes in Tiruchirapalli and seventy in Madurai had joined five hundred low caste converts in

6 Manuel Martins, Madurai, 20 October 1638, ARSI Goa 53, l 12v-1 13v.

7 She may not have been entirely wrong: from the sixteenth century, trading networks had facilitated the spread of independent shrines and cults based around Francis Xavier and St. James (Yãgappann) had spread into the interior. Apart from the sign of the cross or occasionally an image or figure of the Virgin Mary, these shrines and their associated worship did not resemble the cult of European saints. Thus, the sign of the cross may not have been unequivocally associated with the new law in the Tamil country (Bayly 1989: 379-419). 
accepting Christianity. Clearly, even after twenty years, as Nobili himself had begun to see, his sannyāsi model was not reaping a rich harvest amongst the higher castes and, as Martins acknowledged, the mission's demographic base was still the lower castes.

A further impetus to change was provided by the serendipitous conversion of a group of Paraiyans. In Tiruchirapalli, a pious convert of the blacksmith caste had convinced a Paraiyan panțāram, a non-Brahmin Śaiva penitent, of the truth of the new law and accordingly he had approached Antonio Vico for baptism and instruction. ${ }^{8}$ Vico, as a Brahmin ascetic who was forbidden to consort with the lower castes, took the risk and converted the untouchable panțāram, exhorting him in turn to convert his many followers. Not long afterwards, some three hundred Paraiyan converts built their own church to which Vico and Martins would go stealthily for fear of the consequences, should their high caste converts learn of it. Pained that they could not baptize these faithful, Martins was attending the Provincial Congregations in Cochin when the famous visionary Pedro de Basto came to him, and without any preliminaries, encouraged him. Heartened, Martins returned and began baptizing the Paraiyans in secret but as soon as the high caste converts found out, they destroyed the Paraiyan church and arrested the panțaram and chief catechumens. Although they relented, it was clear the Brahmin Jesuits could not consort with the Paraiyan converts who now numbered about two hundred and were tended to by the catechumens, who were acting as preachers in their own right. The Provincial Manuel de Azevedo then decided to send someone to take charge of them.

It was in this process of reinventing the mission that Costa would play a crucial role. Born in 1610 in Aldeia Nova, Portugal, Costa entered the Society on 20 June 1627, in Lisbon. After studying Latin and Philosophy in Coimbra, he sailed for Goa on 13 April 1635, on the same boat that carried the soon to be martyred Marcello Mastrilli. Costa completed his studies before joining the mission on the Fishery Coast, where the storied mission to the Paravas was again entangled in a jurisdictional tussle with the lay clergy. ${ }^{9}$ It was here that Costa received his call to the Madurai mission.

In the garb of a panțāram and with pierced ears, on July 4, 1640, Costa left for Karur, four days journey outside Madurai, where his superiors believed he would be able to cultivate the Paraiyans without offending the "nobility" of the Madurai mission. ${ }^{10}$ Even now, in his new garb, it seems he continued to follow the precepts of Nobili, tending to the Paraiyan only under cover of

8 See Baltasar da Costa, 14 October 1646, "Relação Annua da Missão de Maduré desde Outubro de 644 até o de 646", Doc. 432, Jesuit Madurai Mission Archives, Shembaganur.

9 Manoel de Azevedo, 1 January 1639, letter to Mutio Vitelleschi, Goa 18, 155-156v, Archivum Romanum Societatis Iesu, Rome.

10 Baltasar da Costa, August 1640, Doc. 420, Jesuit Madurai Mission Archives, Shembaganur. 
night. He was, however, much impressed with their devotion and their unity, "as if they were the children of the same father."

Still, Costa's trials started early. After receiving permission from the local Nāyaka revenue official to build a church, the Brahmans and panțārams of the local temples warned the maniyakkärar that they would leave if the church was built as it was Costa's intention to destroy their gods. ${ }^{11}$ Eventually, Costa received a plot on the other side of the river to erect a church which the Christians could attend without drawing attention to themselves and in which the Paraiyans could hear mass without entering it, as the church had a special enclosure for them. The rudimentary church nonetheless attracted seventy new converts but Costa's activities were interrupted by a fresh crisis.

Rumors had been circulating of a coming persecution of the Christians in Tiruchirapalli and it took little provocation to turn rumor into reality. Sebastião Maya described the immediate cause of the persecution from prison. ${ }^{12}$ A wealthy and powerful Paraiyan sought a Christian neophyte's daughter for marriage and was refused since he had not converted. Enraged, he enlisted "a great number of Pandaras, malignant people" and, bearing great gifts, they approached Vacantarayapillai. This was "a man of low condition by blood" who had risen to great influence in the court, since his sister had been taken by the Nāyaka himself from a temple as his courtesan. The repression, when it came, began in Tiruchirapalli, the seat of the Nãyaka court and on Sunday 22 July, 1640 soldiers burst into the church, seizing the Brahmin who was helping at mass, imprisoning him upon royal orders for preaching, despite "being a Brahmin," a "new law" to the Paraiyans. Father Martins, hearing this, offered himself as the most culpable and was summarily seized, imprisoned and then, on the following day, exiled. The Brahmin convert and thirty others remained in prison. Martins travelled towards Senji but sent a neophyte to Baltasar da Costa to warn him in Karur and then onto Madurai to warn Maya and Nobili. Unfortunately, the warning arrived too late and by the time he arrived in Madurai, Maya and Nobili had already been imprisoned.

Maya's report revealed the basic problem in the Madurai mission's adoption of accommodatio based on Brahminical norms of purity: while undoubtedly such an ideology was operational in the region, the Nāyaka polities had begun to elaborate a radically different ideology of kingship and hierarchy, based on their proud identity as śudra kings, "with strong links to trade [and] a marked heroic and martial orientation, in contrast with other trading groups" (Rao,

11 The fact that Costa could receive permission to build a church only ten days after arriving or find the minimal financial resources to do so seems to fit larger patterns of the building of religious monuments in the Nayyaka regions and their desire to diversify the religious bases of their support (Rao, Shulman and Subrahmanyam 1993: 89-90).

12 Sebastião Maya, 8 August 1640, "Relação da persiguição da christandade de Maduré e prisão dos padres daquella missão”, Goa 53, ff. 123-126, Archivum Romanum Societatis Iesu, Rome. 
Shulman and Subrahmanyam 1993: 73-74). The Nāyakas did away with "the formal identification of kingship with the ideology of dharmic norms, as well as $[\ldots]$ the still vital distinction between the worlds of temple and palace" (Rao, Shulman and Subrahmanyam 1993: 67). In such a system, the Brahmin was unequivocally the servant of the king so that "the Dumontian portrayal of a hierarchical order of ever more encompassing forms culminating in the Brahmin (with an encompassed, even 'secularized' Kshatriya ruler beneath him) simply cannot describe Nāyaka society or the political order it produced" (Rao, Shulman and Subrahmanyam 1993: 79).

Moreover, the Nāyaka had elaborated a court system whose "stable dramatis personae" consisted of three elements: "first, the self-made, individualized hero who wins himself a throne, in the complete absence of any proper royal pedigree; second, the merchant-lord who underwrites this assumption of power; third, the courtesans who confer - as only they are able to - symbolic recognition of the achieved status" (Rao, Shulman and Subrahmanyam 1993: 20). In Maya's description of the rich Paraiyan affronted by the refusal of a girl who would confer upon him the symbolic status due to him, of Vacantarayapillai and his origins and rise to power, of the treatment of the Brahmin seized in the church, one may observe the enactment of peculiarly Nāyaka scripts of power, which exceeded and, indeed, competed with the Brahminical ideology of purity. It also revealed the vulnerability of a missionary strategy which relied purely on this latter system in the Nāyaka context.

Nobili eventually managed to send word to Costa, instructing him to go to Madurai to tend to the Christian Brahmins there. He specifically told him to revert to his black cassock, as a foreign priest was preferable to a low-caste panțāram there. ${ }^{13}$ This dramatic episode marked the beginning of the play of identities necessary to navigate the Nāyaka context that would define Costa's missionary career. ${ }^{14}$

\section{ETHNOGRAPHY, ACCOMMODATIO AND IMITATIO}

\section{IN COSTA'S PANTARRAM MISSION}

Costa's view of Nāyaka society can be best discerned in a report penned in 1646, which included a section on the castes of that land. ${ }^{15}$ Costa began with the traditional classificatory system: the Brahmins, the first caste which sprang forth from the breast of Brahma; the komatis or cettis of the third caste who

13 Baltasar da Costa, August 1640, Doc. 420, Jesuit Madurai Mission Archives, Shembaganur.

14 The possibility for this play of identities may in itself have been an artifact of the peculiarities of Nãyaka society: the blurring of boundaries and "a general fusion of symbolic domains" was a "diagnostic feature of the period as a whole" (Rao, Shulman and Subrahmanyam 1993: 87).

15 See Baltasar da Costa, 14 October 1646, "Relação Annua da Missão de Maduré desde Outubro de 644 até o de 646", Doc. 432, Jesuit Madurai Mission Archives, Shembaganur. 
emerged from his thighs, the sudras from his feet. However, he quickly dismissed this schema as untrue to social reality, noting that in this division no mention is made of the untouchables from whence the majority of the Christians came and whom he championed as the best, employing Christian metaphors of the greatness of the humble. Thus, discarding this schema, Costa organized his discussion in a tripartite division of high, middle and low castes, corresponding to Brahmans; kings, merchant castes like komatis, and śudras; and the untouchable Paraiyans.

Costa's description of the Brahmins was savagely critical, accusing them of divine pretentions and noting particularly their obsession with purity. Costa then moved on to his second group, which formed the core of Nāyaka society. Among this group, he averred the kings occupied the first place, noting the heroic ideal they embodied as they were born soldiers who died bravely. Next, he dealt with the trading castes, followed by brief descriptions of marriage customs, kinship relations, certain peculiarities of a subset of the Vella âla caste. ${ }^{16}$ It was a very astute understanding of the nature of Nāyaka kingship, which combined the warrior-like qualities of the kingly castes, without denying their sudra origins, and in which wealth, earned through trade and commerce, could provide a means to political power. He thus correctly classified the kings alongside these left-hand castes, the political elites of Nāyaka society; further, he understood the extent to which Nāyaka political culture centered on wealth and conspicuous consumption. ${ }^{17}$

Costa's most sympathetic portrayal was reserved for the Paraiyans, who, as he explicitly noted, mirrored the Brahmins: their yogis too were blessed with prodigious memories but whereas the Brahmins specialized in superstition, they learnt the moral sayings of a saint whom Costa suspected of having been contemporaneous with, if not a disciple of, Saint Thomas and who had declared that God should become man and suffer. ${ }^{18}$ The high-standing of this

16 Though Costa agreed with Nobili regarding the social rather than religious significance of the insignias of caste, it is worth nothing that his report has a similar sensitivity to the minutia of local custom displayed in Gonçalo Fernandes' treatise of 1616, which was explicitly at odds with Nobili's Brahminical reconstruction of Madurai society.

17 See, for example, his description of Tirumala Nāyaka's kingdom. Costa did, however, misunderstand the Nāyaka relationship to Vijayanagara, in characterizing the Nāyaka's actions towards their nominal overlords as disloyal. He was also critical of the financial burden on the agricultural system on which this political system was erected, speaking of rapacious modes of taxation, the poverty of the people, and reporting common jokes regarding the acquisitiveness of the Nāyaka king (Costa 1646).

18 The figure Costa was referring to was undoubtedly Tiruvalluvar, the author of the Tirukkural (ca. 450-550 AD), one of the most important texts in the Tamil canon (Cutler 1992). His identification with the valluvar allowed the Paraiyan to claim him, as the valluvan is a Paraiyan caste of royal drummers and ritual practitioners for the Paraiyans. Tiruvalluvar was identified strongly with both São Tomé or Meliapor, a Portuguese stronghold, and Madurai. By the late sixteenth century, the Portuguese had already begun to cast the poet as a disciple of Saint Thomas (Subrahmanyam 2001: 37-38). 
poet among the Paraiyan proved their disposition for the Christian faith, in contrast with the Brahmins who, despite their intelligence, remained implacably obstinate. Costa averred that only one in three Brahmin converts would persist in the faith, if they were won over at all.

It was this obduracy which had undone Nobili's great project of converting the Brahmins in the mistaken hope that, since they were so revered, their conversion would induce the whole kingdom to follow. Still, Costa was adamant that one should not abandon the underlying method Nobili had elaborated. Since Brahmins could not accept their religion from those of an inferior caste, Nobili's method kept the door open for them. The mere fact that there were Brahmin Christians justified the sannyāsi mission, and set an example for other castes. ${ }^{19}$ Moreover, unlike Gonçalo Fernandes, Costa agreed with the crucial distinction Nobili had drawn between caste and faith: he approved of attempts to disabuse Indians of the notion that conversion would entail the loss of caste, an error spread by early linguistically incompetent missionaries who had asked natives to become Christians and enter the caste of the Portuguese.

The most important reason, however, for defending Nobili's mission was because of the example it set of missionary endeavor:

"And when all this does not seem enough for this mode of saniazes, just consider the great honor and credit that follows our company, for it is patently obvious that the whole world has heard that its sons labor to follow the ends of their institute, doing for this such extreme things, that, not content with depriving them for all their life of their own country, but also the customs with which they grew up, exchanging them for others as barbarous as they are difficult, acting with Brahmins, as Brahmins, with Pâreas, as Pâreas."20

Costa's words here are an ironic echo of Nobili's own judgment regarding the relative aptitude of Italians and Portuguese Jesuits to conform themselves to the demands of radical accommodatio: Italian missionaries, Nobili had averred, could cast off their national customs with ease, becoming "all to all," which the Portuguese could not do without great difficulty. ${ }^{21}$ It would seem then that Costa in his person had belied Nobili's judgment of the capacity of Portuguese missionaries to conform themselves to the demands of accommodatio.

19 Manuel Martins makes a similar argument for the value of the sannyāsi model even as Brahmin converts declined (see Manuel Martins, 31 October 1651, Letter, Goa 53, ff. 219-222, Archivum Romanum Societatis Iesu, Rome).

20 Baltasar da Costa, 14 October 1646, "Relação Annua da Missão de Maduré desde Outubro de 644 até o de 646”, Doc. 432, Jesuit Madurai Mission Archives, Shembaganur.

21 Roberto Nobili, 21 October 1610, Letter, Goa 51, f. 165, Archivum Romanum Societatis Iesu, Rome. 
Accommodatio, the principle of adapting oneself to the dispositions of the audience, was not peculiar to Nobili and was arguably a part of Jesuit practice from the very beginning: the eighteenth annotation of Ignatius of Loyola's Spiritual Exercises enjoins the giver of the exercises to adapt them to the dispositions of the persons who wish to receive them. Its roots lay in the Judeo-Christian exegetical principle that "the Scriptures speak a human language," which laid open the metaphorical and allegorical language of scripture to hermeneutic interpretation (Funkenstein 1986: 202-289). The concept intertwined rhetoric and theology: Augustine, in explicating why Jewish customs were now condemned by the Christian God, had drawn upon Cicero's notion of appropriateness in De Oratore. Thus, "the rhetorical notion of the appropriate, the fitting, allowed Augustine to sustain simultaneously the ideas of divine immutability and of historical change" (Ginzburg 2001: 1 10-1 12). Augustine's crucial temporalization of Cicero's rhetorical concept eventually paved the way for Jesuit missionaries to add to it a spatial dimension: the principle of accommodatio allowed missionaries such as Matteo Ricci and later Nobili and Costa to transcend the contingencies not only of time but also of space, in spreading the Christian message.

Yet, accommodatio was difficult, as Costa himself acknowledged, though he denied that this was reason to abandon Nobili's method: "Nor should those be heard who say that such a mode cannot be conserved due to its difficulty, for they do an evident injury to the spirit of the Company, for its sons with news of the slow fires of Japan still do not step back from that mission". ${ }^{22}$ Costa thus exhorted his brothers in Portugal to come to Madurai, by explicitly comparing its difficulty and thus worthiness as a mission field to Japan. ${ }^{23}$

In this light, Nobili's method was invaluable not because of its limited success in converting Brahmins but because of its exemplarity as a life of a missionary. To use Costa's own metaphor, the delicacy of Nobili's method was picked out against the dark background of his relative failure among the Brahmins, like stars which shine brighter against the obscurity of the night. As Costa put it, "The Sun of justice incarnate was made known when he was nailed to the cross more than when he argued brilliantly among the Doctors." If Nobili's brilliant arguments among the doctors had failed, he had nonetheless laid open the path to a model of missionary hardship, if not martyrdom, through which the Christ, the Sun of justice, could be made known.

Costa's critique rested on a subtle distinction in Nobili's method between the principles of accommodatio and imitatio, another concept with deep theological

22 Costa may well have been thinking of the martyrdom of Mastrilli, his erstwhile companion on the long voyage to the Indies. See Baltasar da Costa, 14 October 1646, "Relação Annua da Missão de Maduré desde Outubro de 644 até o de 646”, Doc. 432, Jesuit Madurai Mission Archives, Shembaganur. 23 It was not an idle comparison, since Pedro de Basto himself had apparently prophesied to Costa, "Be greatly consoled that in Madurai there is another Japan". 
and rhetorical roots. ${ }^{24}$ Imitatio christi was not only the orienting principle for the Christian life but the foundation of a praxis centered on exemplary lives, most obviously but not exclusively evident in the cult of saints. As made clear in Augustine's Confessions, itself intended as an exemplary conversion narrative, imitation, though not a substitute for divine grace, is an instrument of it. This was one reason why, in Augustine's account, pagans who lacked the "pattern of divine humility" were consequently unable to return to God (Herdt 2008: 66-71).

Costa's defense of Nobili's method thus rested on its exemplary value in the tradition of Christian imitatio to other missionaries, more than for its success as accommodatio to Madurai society. This idea is most explicitly expressed in Costa's epitaph to Nobili, which recalled his earlier celestial metaphors. ${ }^{25}$ Nobili, the sun that rose in the West to set in the East, could not be eclipsed by the minor planets that conspired in vain against him. Instead, he illuminated many others, most notably the missionaries who followed him to Madurai, the "stars" who would illumine the firmament of Madurai, "borrowing the light" of that original sun, "as mirrors reflecting the Sun's rays produce as many Suns as there are mirrors." Through his method, Nobili lived on since "Madura has as many Nobilis as there are laborers." Thus, though he dressed in the garb of a panțāram, Costa was still imitating Nobili, not in a simple sense of reproducing his likeness, but rather in a procedural sense, like a mirror borrowing the light of a sun to become another sun.

Nobili's method was thus of undisputable value for Christian imitatio; however, the sannyāsi model was flawed as a template for accommodatio in Madurai since it was based on a faulty ethnography of Madurai society which gave inordinate importance to Brahmins. Costa's ethnographic schema, which gave prime importance to the new Nāyaka elites, instead suggested a different object for Jesuit mimetic practice in Madurai, one aimed precisely at accommodating these elites rather than intractable Brahmins.

It is important here to note that Costa was not suggesting that accommodatio and imitatio were opposed, in and of themselves. Indeed, the dovetailing of these concepts in the idea of providing a pattern of Christian virtue, accommodated stylistically to a particular audience, nourished much early modern thought, not least Jesuit pedagogical theater (Herdt 2008: 129-170) ${ }^{26}$ Nonetheless, if

24 The concept of imitatio also had a philosophical dimension, deriving from Plato and Aristotle, evident in such domains of Scholastic thought as the critique of hypocrisy as a vice, or the reconciliation of habituation in Aristotelian virtue ethics with Christian praxis. While this tradition continued, the rise of humanism and Augustinianism made the rhetorical tradition relatively more salient in the period under discussion here.

25 See Baltasar da Costa, 1661, Catecismo em que se Explicão Todas as Verdades Catholicas Necessárias pera a Salvação com Excellentissima Ordem, Vermelha 698, Academia das Ciências, Lisbon.

26 Following Ginzburg, it appears that the rhetorical idea of style, which allowed that [continua] 
this period witnessed a flowering in the religious and rhetorical theory and practice of imitatio, it saw a concomitant preoccupation with hypocrisy and dissimulation, one manifestation of which was precisely anti-theatricality. ${ }^{27}$

For a Jesuit to style himself as panțāram was thus a fraught affair, despite precedent, since it placed him uncomfortably close to the morally ambiguous figure of the actor, not to mention the object of his mimesis, a pagan priest. This discomfort may be witnessed in Costa's description of the panțārams, the model for his mimetic practice. ${ }^{28}$ Their "incredible" activities Costa compared to the character Don Pablos de Buscón from Francisco de Quevedo's picaresque novel, a swindler who failed in his two goals of learning virtue and becoming a gentleman. The allusion suggested not only the upstart social ambition of these religious penitents, who served members of the second category of castes of Nāyaka elites in Costa's schema, but was also a pointed comment on their inability to orient themselves to spiritual rather than social values. The critique was coupled with an attempt to distance himself from those who served as his model in Madurai: Costa claimed he had adopted the dress of the most respectable among them, enclosing a sketch for reference, since the others either wore comical attire or went nearly naked in a manner that resembled the devil.

In this report, and many others, the panțārams emerge as Costa's prime antagonists as well as his distorted mirror image, his "monstrous double," locked as they both were in a battle for the hearts of the lower castes. ${ }^{29}$ Yet, his oppositional stance to the sannyassi mission's focus on Brahmins and his clear preference for evangelizing to the lower castes suggested that, along with markers of panțāram identity upon his body, he had adopted the social viewpoint of the panțāram, based not on Brahminical ritual purity but on Nāyaka notions of power and hierarchy subtended by the dramatic rise of the very castes the panțāams served.

Costa's seemingly paradoxical relationship to the panțäram is best considered in light of the rich variety of mimetic practices entailed by imitatio in humanist thought, which allowed both the obscuring of a model, either through a digestive or dissimulative process, and its explicit acknowledgment through aemulatio, whether as tribute or as competitive critique. ${ }^{30}$ Thus, Costa's mimetic practice could be strictly dissimulative, for the purposes of camouflage while

excellence could be achieved by a variety of incomparable means, provided a general framework to bring together accommodatio and imitatio in Jesuit pedagogical theater.

27 The classic works on these subjects which have since generated much scholarship are Barish (1980) and Zagorin (1990).

28 See Baltasar da Costa, 14 October 1646, "Relação Annua da Missão de Maduré desde Outubro de 644 até o de 646”, Doc. 432, Jesuit Madurai Mission Archives, Shembaganur.

29 The term is taken from René Girard's discussion of the violence towards the rival born of mimetic desire (Girard 2005: 152-158, 174-178).

30 The typology is from Pigman (1980). 
travelling through bandit country. ${ }^{31}$ Yet it could also be eristic, invoking the model precisely to highlight difference from it.

One can discern this in Costa's skillful negotiations of the Nāyaka courts. At a time when the divisions of temple and court were beginning to dissolve and the Nāyaka kings claimed equal dominion over both, it is not surprising that many of Costa's reported religious disputations with the panțārams occurred, at his insistence, before the Nāyaka rulers and not in temples. One such royal audiences occurred before the Nāyaka in Sathyamangalam, to whom Costa turned for relief from a series of laws promulgated under the aegis of the local panțārams, to force all inhabitants to contribute to the sacrifice during a feast, thus undoing the conversions Costa and his catechists had effected in the region. The exchange with the king was reported as direct speech:

"[The Nãyaka asked:] 'this law that you preach, is it one of the four of these parts?' 'The good merchant' I replied, 'if he wants to make good fortune, when he goes to foreign kingdoms, does not carry to it the merchandise which they have in abundance and just so the merchant of salvation of souls does not do well to bring in this kingdom laws which are taught in it. The law which I preach is as different from yours, as the truth from falsehood'." 32

Costa's panțāram identity and mode of behavior was a means to make palatable without denying the essential newness he was bringing into the Tamil country, a newness that was both coin and danger in this religious marketplace. In the same way that he brought unusual foreign gifts like organs and prisms for Nāyaka kings, he also brought a new law to their courts.

The mercantile metaphor commands attention. It was singularly apt for the Nāyaka audience, whose courtly literature celebrated wealth and commerce in new ways. Costa's comparison of himself as a religious figure to a merchant was befitting both as a panțāram, priest to the merchant castes, and as a Jesuit missionary, for whom the use of commerce discursively and literally was sanctioned by the example of Francis Xavier himself (Županov 2005: 60-65). Indeed, Costa's epitaph for Nobili described how Nobili had drawn gold from the viscera of this infertile land and exhorting the "traders," those "who conduct the Society's transaction," to buy the "Madurean field in which such treasure is hidden," to repay with interest the debts owed to the Lord. ${ }^{33}$ Moreover,

31 Baltasar da Costa, 1644, "Relazione del successo nella Missione de Maduré delli 8 di Iuglio 1643 insino a 29 d'outobre de 1644", Doc. 430, Jesuit Madurai Mission Archives, Shembaganur.

32 Baltasar da Costa, 14 October 1646, "Relação Annua da Missão de Maduré desde Outubro de 644 até o de 646”, Doc. 432, Jesuit Madurai Mission Archives, Shembaganur.

33 Baltasar da Costa, 1661, Catecismo em que se Explicão Todas as Verdades Catholicas Necessárias pera a Salvação com Excellentissima Ordem, Vermelha 698, Academia das Ciências, Lisbon. 
the comparison allowed Costa to invoke the benevolent view that the Tamil country could take of European merchants, exemplified by Viśvāsu in the epigraph above.

As the multivalence of this metaphor suggests, Costa's mimetic self-fashioning drew upon the familiar figures of the panțāram and the white-face merchants in the Tamil country, as much as his Jesuit predecessors. Moreover, his mimetic practice affirmed difference as vociferously as it claimed likeness, drawing attention to or obscuring the various European and Tamil models on which his persona was based. As a Christian missionary to the non-Brahmin castes of Madurai, the success of his enterprise was dependent on seeming like a panțaram but marking himself as different from the Hindu priests who bore that name. In the lands of the Nāyaka kings, who so valued commerce and wealth, and wondrous new things, Costa wished to appear as a foreign merchant, but one who brought spiritual not material wares. To maintain the legitimacy of his missionary practice and of the Madurai mission in general in the larger Jesuit order, Costa both embraced his role as a committed disciple of Nobili while subtly setting himself apart from his mentor. Costa's creative mimesis, in transforming imitatio into inventio, was thus in line with a venerable tradition of European humanism, perhaps best represented by Erasmus:

"I approve an imitation that is not limited to one model from whose features one does not dare to depart, an imitation which excerpts from all authors $[\ldots]$ what is excellent in each and most suits one's intellect $[\ldots]$ [so that it] appears to be a birth of one's intellect [...] an image breathing forth one's mind or a river flowing from the fountain of one's heart" (Pigman 1980: 8-9). ${ }^{34}$

\section{The limits of bi-directionality}

Costa's panțâram mission was witness to a rapid increase in the number of converts, and shortly after Costa's death, it had replaced the sannyāsi model entirely (Županov 1999: 235). ${ }^{35}$ On the surface, this alone appears to be a deep vindication of the success of Costa's mimetic model. Yet, it is doubtful the extent to which this "success" was a result of Costa's own agency. As Costa himself acknowledged, the mission would have foundered without the energy and activity of the leading converts of Madurai, examples of whose enormous

34 Pigman argues that “suits one's intellects” referred to Erasmus' critique of blind Ciceronianism, with its pagan terms, on the basis of historical appropriateness in a Christian age. Thus, Erasmus too draws together imitatio "of what is excellent" with Christian accommodatio in this model.

35 The sannyāsi mission ended in 1673. However, as Županov (1999: 28) rightly points out, even the panțāram model was not sustainable in the long run due to the lack of missionaries and the willingness of converted clans to turn to other ritual practitioners. 
energy and exemplary virtue abound in Costa's writings. ${ }^{36}$ In 1646, there were only two fathers dressed as Brahmin sannyāsis who interacted solely with the highest castes (Fathers Nobili and Martins) and two panțāram Jesuits - Costa himself and Manuel Alvarez. With so few missionaries, regardless of the fruits of accommodatio, they relied heavily on native catechists.

First among these native catechists was Savery Rayan, or Peter Xavier, who proved particularly useful because of his knowledge of "all the sects of this land," so that even scholars feared disputing with him. He had come to Christianity through a curious act of will and reason: discontented with the tenets of various native creeds and learning that the Portuguese worshipped "one god," he had eventually set out towards São Tomé but serendipitously met some Christians in Tiruchirapalli. Constantine had been a yogi before his conversion and his former life again proved useful in providing ammunition against disputants. Costa mentioned in particular his training in music, which allowed him to gather crowds wherever they went, thus providing alms for Costa and himself on their travels and drawing in potential converts. Glorioso, a former panțāram and the first convert of his caste, had brought several hundred of his disciples into the fold. As a former panțaram, he almost certainly proved a particularly useful native informant to Costa.

Conversion in the Madurai mission was thus often directed largely by natives themselves. Costa joyfully reported, for example, that the conversion of two hundred members of the Vella la la caste in Sathyamangalam had occurred through the intercession of a lowly Paraiyan. The Paraiyan convert had spoken to them of the new faith movingly and with good effect so that, much like the blacksmith convert who had taken the Paraiyan yogi to Vico, the Paraiyan convert came with a deputation of the Vell âla leaders to request instruction and baptism. Costa himself went to Madurai to consult with Nobili before undertaking the journey but sent Peter Xavier along with them. By the time Costa arrived, the catechumens were ready for baptism. The entire process had occurred without a single action taken by the European Jesuits themselves. ${ }^{37}$

Through conversion, native catechists had greatly expanded their own agency in Madurai society, finding new avenues for religious and political leadership regardless of caste. Indeed, Christianity spread through caste and kinship networks as a way for ambitious but marginal caste groups to enhance their status; thus, as Susan Bayly has shown, the martial Maravars could assimilate Christianity into their caste identity, in a way not dissimilar to the promotion by warrior clans of their own non-Sanskritic deities (Bayly 1989:

36 See Baltasar da Costa, 9 September 1653, "Annua da missam de Madurê", Doc. 446, Jesuit Madurai Mission Archives, Shembaganur.

37 See Baltasar da Costa, 1644, "Relazione del successo nella Missione de Maduré delli 8 di Iuglio 1643 insino a 29 d'outobre de 1644”, Doc. 430, Jesuit Madurai Mission Archives, Shembaganur. 
394-398). Indeed, the adoption of Christianity came eventually to be seen by the latter half of the century as "an act of statecraft" by warrior chiefs "to define and stabilize" their own domain and claim sovereignty from their overlords (Bayly 1989: 396-401).

Moreover, it was undeniable that these native catechists were significantly more effective in evangelizing to their brethren than the Jesuits themselves. While Costa's successful adoption of Nāyaka symbolic expressions of power allowed his followers to claim a legitimate form of authorization for their activities in Nāyaka society, the artifice of mimicry was never quite erased. ${ }^{38}$ It ensured that the white-face panțārams could secure only a precarious position in Nāyaka society: one need consider only the periodic persecutions of the Jesuits, culminating in the martyrdom of João de Brito in the following generation, to see the limited efficacy of Jesuit accommodatio as Nāyaka political praxis.

To some extent, the alterity maintained through mimesis was incumbent upon Costa. As a Catholic missionary, he could not abandon the ontological ground upon which his faith and vocation was founded. Moreover, for the sake of his evangelical mission he had to differentiate himself from his pagan mirrors and foils in the eyes of potential converts. ${ }^{39}$ Nonetheless, the efficacy of the native catechists did raise the question why they could not be made full clergy or even Jesuits in their own right, making moot the need for mimesis as a missionary strategy. It was a question made increasingly sharp by the Propaganda Fide's contrasting policy of promoting native clergy in India. In the end, it appeared that the alterity maintained through mimesis of Tamil religious figures by the Jesuits was less threatening than the erasure of difference implied by the full acceptance of Tamil converts into the Society of Jesus.

A second, perhaps less obvious source for the ways in which Costa's mimetic practice was ultimately invested in a defense of alterity was to do with his peculiar position as a subject of the Portuguese empire. Despite Costa's determination to disprove Nobili's doubts regarding the mimetic ability of the Portuguese to become "all to all," Costa never overcame his particular concern for Portugal and its empire. While he was undoubtedly committed to his missionary vocation, he was also concerned for the Portuguese empire for its own sake and not solely as an expedient for universal conversion.

The contradictions of this double commitment became apparent when the padroado became increasingly ineffective, undermining the notion that Portuguese dominion was necessary for the spread of Christendom in India.

38 On the way in which mimicry, in taking on "the insignia of authority," can lay bare the symbolic expression of power in a subversive way, see Bhabha (2006 [1994]: 172). Note that his discussion is explicitly intended for the case of mimicry in a colonial context, an issue to which I return below.

39 On this notion of the dialectical relationship between alterity and mimesis, see Taussig (1993: 129). 
A devastating series of attacks by the Dutch from the 1650s, culminating in the traumatic loss of Cochin by 1653, had forced the papacy to step up its efforts to counteract the effects of the loss of Catholic temporal jurisdiction. ${ }^{40}$ This led to the launch of its independent missionary efforts under the Societé des Missions Etrangères in Paris. The reaction from the Estado da Índia to this encroachment of the padroado was expectedly hostile, not least because of the influx of foreign missionaries. ${ }^{41}$ These missionaries were viewed by the Portuguese, not without reason, as an advance guard of foreign imperial ambitions in the region, who would stir local sentiment against the Portuguese. ${ }^{42}$ The fact that the impoverished Estado da Índia could barely acquit the demands of the padroado only made matters worse. ${ }^{43}$

Given the weakened condition of the Portuguese and the increasing influence of Rome, the traditional Jesuit strategy of asserting loyalty to the Estado da Índia and the padroado to garner Portuguese support in their various disputes was increasingly ineffective. ${ }^{44}$ The Malabar province was faltering. In Madurai, Costa felt these winds of change, most obviously through the acute financial pressure on the mission after the fall of Cochin. ${ }^{45}$ Still, his concern was not solely for the Jesuit mission or the business of conversion. Portuguese attrition in both temporal and spiritual domains had awakened in him sentiments which he had so proudly set aside in conforming himself to the demands of Nobili's method.

His concern for the preservation of the Portuguese Estado da Índia can be glimpsed in the prefatory notes to his translation of Nobili's short catechism from Tamil into Portuguese. ${ }^{46}$ To the reader, Costa addressed a vigorous

40 For a detailed list of engagements, see the introduction of Galletti, van der Burg and Groot (1911).

41 The beginnings of this encroachment could be traced to the bull Apostolicae sedis of 1608, in which the Jesuit monopoly of Japan under the padroado was revoked (Boxer 1993: 239-241; Paiva 2000). On the Estado da Índia's concern about incoming foreign missionaries, see for example, AHU India 44, Doc. 23, September 12, 1661.

42 See, for example, the complaints about the French bishop of the Serra and also against Mateus de Castro, who is accused of stirring the Mughals, native subjects of the Estado da Índia and the Dutch against the Portuguese. AHU India 44, Doc. 57, January 12, 1662.

43 On the inability to support the padroado financially, see for example AHU India 45, Doc. 116 , August 29, 1662.

44 For examples of the Jesuit strategy of claiming loyalty to the Portuguese against Franciscans or the episcopacy, see ANTT, Cartório Jesuítico, 90, Doc. 123; AHU India 44, Doc. 26, September 16, 1661. On the fractious relationship between Jesuits and papal representatives, see Biblioteca nazionale central di Roma (BNCR), Fondo gesuitico, 1255, Doc. 19.

45 The costs of Madurai to the padroado had been a potent weapon against Nobili and Costa too was sensitive to this. On difficulties of receiving payment in Madurai, see, for example, ANTT, Cartório Jesuítico, 90, Document 66. On the dire financial condition of the Malabar province, see BNCR, Fondo gesuitico 1384, Doc. 34.

46 Baltasar da Costa, 1661, Catecismo em que se Explicão Todas as Verdades Catholicas Necessárias pera a Salvação com Excellentissima Ordem, Vermelha 698, Academia das Ciências, Lisbon. 
defense of Nobili's method, before explaining the purpose of his translation using a mercantile metaphor. Knowing the difficulty that missionaries had in learning the language, such that many were struck mute like "merchants who leave the shore to search for necessities each day with too large a coin," Costa explained that the work would allow missionaries to be "merchants who not only had the large coin of wisdom, but also the little one of words with which they could communicate." Even as he emphasised the need for missionaries to speak aptly in Madurai, he excused his own lapses in Portuguese style because he had so rarely used his native language in his twenty-one years there.

The preface bespoke of Costa's ardent commitment to Madurai, the Tamil language and his mimetic practice there. ${ }^{47}$ Nonetheless, the work was an act of translation, an attempt to bring Madurai into conversation with Portugal, which could claim no dominion over it. As such, it was not only meant for fellow missionaries but for the Portuguese king too: "To dedicate to Your Majesty this work $[\ldots]$ was no free action, but due obligation, because in it is contained the holiest law of God and the order with which it should be preached among the Gentiles of the East." Costa referred to the famed vision of D. Afonso Henriques, where Christ chose him not only "as king of Portugal but also as defender and preacher of his holy Law by means of his vassals." Accordingly, the present Portuguese king had "inherited the scepter and the good distribution of the divine law, which is contained in [this] book." 48

The writing, translation and dedication of a Tamil catechism served as the enactment, but also the reminder, of a series of mutually constitutive obligations, subtended by the original obligation of the Portuguese king to Christ. By casting himself as both a missionary and a vassal and presenting his work as an act of feudal and divine obligation, Costa reminded the king of his twin obligations to defend his vassals and spread the divine law in distant lands, as well as his own right to be recognized as a vassal even as a missionary in non-Portuguese lands. In doing so, Costa effected a subtle slippage, placing Madurai, the realm of gentile kings, under Portuguese spiritual if not temporal dominion.

This slippage hinted at imperial ambitions expressed more explicitly in two documents dating from his brief stay in Lisbon as procurator in 1672. The first was a memorial on Dutch intrigues to dispossess both the Portuguese and the Jesuits in India in concert with native kings, particularly the Nāyakas. ${ }^{49}$ The second was a proposal sent to the confessor of D. Pedro, the Jesuit Manuel Fernandes, to recuperate India, whose dire need for expanded seapower could

47 Costa also wrote a grammar of the Tamil language, preserved in Central Library, Panjim, MS M34.

48 The dedication is dated Madurai, 12 February, 1661.

49 See Baltasar da Costa, July 14 1672, "Do que os Olandeses tem feito na India...", 50-V-37, fl. 365 , Biblioteca da Ajuda, Lisbon. 
be met by raising capital through the "gente de nação," in return for a general pardon for the New Christian community. ${ }^{50}$ The proposal, which triggered a decade-long controversy, stemmed from a series of conversations in the Roman house between António Vieira, Costa and Pedro Zuzarte, who had served in Japan, in which they had apparently discussed means of saving the Estado da Índia. ${ }^{51}$ Costa's role ended when he died during a voyage back to India in 1673 at the head of a new group of missionaries destined for Madurai. Nonetheless, the failed dream of an Oriental company, which Costa evidently shared with Vieira, attested to Costa's desire to defend Portuguese dominion in India, a desire undiminished by a lifetime of mimetic practice in the Tamil country and his careful absorption of and adherence to Nāyaka codes of power. Though he could supplicate himself to the Nāyaka kings in the garb of a panțāram and in Tamil, Costa remained a foreign merchant, who peddled his spiritual wares in the name of a distant kingdom.

\section{CONCLUSION}

The bi-directional reading of Costa's life I have essayed here follows the precepts of the historical discipline: using the conceptual tools of his own era, I have attempted to understand Costa in the context of the seventeenth-century European and Tamil worlds. Yet, this conventionally historical reading does reveal a blind-spot in the recent theoretical literature on mimesis in the context of cultural encounter. This literature, often heavily influenced by postcolonialism, has developed its own repertoire of stock characters: the mimic men, the Europeans gone native, even intrepid anthropologists. Costa resembled all these figures - and yet cannot be reduced to any of them. If Costa's mimicry, as disruptive imitation, allowed him to expose the pattern of Nāyaka power, Costa's life can hardly be narrated with the language of mockery and resistance that Homi Bhabha invokes for mimic men (Bhabha 2006 [1994]: 172). ${ }^{52}$ If Costa adopted the garb of the panțāram and spoke in Tamil, his unwavering commitment to his order, to the spread of universal Catholicism and to the Portuguese empire burned like a lamp in the Conradian heart of darkness throughout his life. If his mimesis was based first and foremost on ethnographic observation, it led him to resist, not submit to the fact that "something crucial about what made oneself was implicated and imperilled in the object of study" (Taussig 1993: 253).

50 See Baltasar da Costa, September 7 1672, carta original do Jesuíta Balthazar da Costa..., Armário Jesuítico, maço 29, Doc. 14, ANTT, Lisbon.

51 See Vieira (1953: 48-49, 56-57). On the debates surrounding the proposal, see Hanson (1981: 89-123).

52 The definition of mimicry as disruptive imitation is from Huggan (1997/1998: 94). 
The ways in which a figure like Costa challenges this corpus is not merely to do with his belonging to an era that has generally not occupied these theorists. It is to do with the fact that Costa's mimesis occurred entirely outside the domain of European imperialism, even though he himself bore the imprint of an imperial habitus. The contradiction between his imperial ambitions and the fact of his precarious existence at the mercy of a profoundly alien system of authority may account for the ways in which Costa conforms to and violates the mimetic models sketched above. Certainly, it invites us to consider Costa, and others of his ilk in the long history of Jesuit accommodatio, as the starting point into an investigation of mimesis in these gray zones of imperial history.

\section{REFERENCES}

ARANHA, Paolo, 2008, "Missionary constructions of Hinduism and caste in the controversy on the Malabar Rites ( $17^{\text {th }}-18^{\text {th }}$ centuries)", paper presented at the conference "Rethinking Religion in India", New Delhi, Indira Gandhi National Center for the Arts.

BARISH, Jonas, 1980, The Anti-Theatrical Prejudice. Berkeley, University of California Press.

BAYLY, Susan, 1989, Saints, Goddesses and Kings: Muslims and Christians in South Indian Society, 1700-1900. Cambridge, Cambridge University Press.

BHABHA, Homi, 2006 [1994], The Location of Culture. New York, Routledge.

BOXER, Charles, 1993, The Christian Century in Japan, 1549-1650. Lisbon, Carcanet.

BRONNER, Yigal, 2010, Extreme Poetry: The South Asian Movement of Simultaneous Narration. New York, Columbia University Press.

CUTLER, Norman, 1992, "Interpreting Tirukkural: the role of commentary in the creation of a text", Journal of the American Oriental Society, 112 (4): 549-566.

FUNKENSTEIN, Amos, 1986, Theology and the Scientific Imagination from the Middle Ages to the Seventeenth Century. Princeton, Princeton University Press.

GALLETTI, A. J., P. VAN DER BURG, and P. GROOT (eds.), 1911, Selections from the Records of the Madras Government: The Dutch in Malabar. Madras, Government Press.

GINZBURG, Carlo, 2001, Wooden Eyes. New York, Columbia University Press.

GIRARD, René, 2005, Violence and the Sacred. London, Continuum.

HANSON, Carl, 1981, Economy and Society in Baroque Portugal. Minneapolis, University of Minnesota Press.

HERDT, Jennifer, 2008, Putting on Virtue. Chicago, The University of Chicago Press.

HUGGAN, Graham, 1997/1998, "(Post)colonialism, anthropology and the magic of mimesis”, Cultural Critique, 38: 91-106.

MINKOWSKI, Christopher, 2004, "On Suryadasa and the invention of bi-directional poetry (vilomakavya)", Journal of the American Oriental Society, 124 (2): 325-333.

MOSSE, David, 2012, The Saint in the Banyan Tree: Christianity and Caste Society in India. Berkeley, University of California Press. 
PAIVA, José Pedro, 2000, "A Igreja e o poder", in Carlos Moreira Azevedo (ed.), História Religiosa de Portugal, vol. 2. Lisboa, Círculo dos Leitores, 135-185.

PIGMAN, G. W., 1980, "Versions of imitation in the Renaissance”, Renaissance Quarterly, 33 (1): $1-32$.

QUEYROZ, Fernão, 1689, Historia da Vida do Veneravel Irmão Pedro de Basto.

RAO, Velcheru Narayana, David SHULMAN, and Sanjay SUBRAHMANYAM, 1993, Symbols of Substance. New Delhi, Oxford University Press.

Subrahmanyam, Sanjay, 2001, Penumbral Visions: Making Polities in Early Modern South India. Ann Arbor, University of Michigan Press.

Subrahmanyam, Sanjay, 2002, The Political Economy of Commerce: Southern India, 15001650. Cambridge, Cambridge University Press.

TAUSSIG, Michael, 1993, Mimesis and Alterity. New York, Routledge.

VEṄKAṬĀDHVARIN, 1825, Viswagunadarsana; or Mirror of Mundane Qualities, trans. Caveli Venkata Ramaswami. Calcutta, s/ed.

VIEIRA, António, 1953, Obras Escolhidas, vol. 2, ed. by Antonio Sergio and Hernani Cidade. Lisbon, Livraria Sá da Costa.

ZAGORIN, Perez, 1990, Ways of Lying. Cambridge, MA, Harvard University Press.

ŽUPANOV, Ines, 1999, Disputed Mission: Jesuit Experiments and Brahmanical Knowledge in Seventeenth-century India. New Delhi, Oxford University Press.

ŽUPANOV, Ines, 2005, Missionary Tropics. Ann Arbor, University of Michigan Press. 